\title{
Kearifan Lokal Komunitas sebagai Modal Sosial dalam Manajemen Bencana Alam
}

\author{
Untoro Hariadi, Suratman,Totok Gunawan dan Armaidy Armawi \\ Universitas Janabadra, Fakultas Geografi, Universitas Gadjah Mada, Yogyakarta. \\ Email Koresponden : untorohariadi67@gmail.com
}

Direvisi: 2019-01-03. Diterima: 2019- 08-22

(c)2019 Fakultas Geografi UGM dan Ikatan Geograf Indonesia (IGI)

\begin{abstract}
Abstrak. Penelitian ini bertujuan mengkaji kearifan lokal komunitas sebagai modal sosial dalam manajemen bencana alam untuk memperoleh gambaran secara utuh tentang makna substantif dari komunitas, kearifan lokal dan manajemen bencana alam. Metode penelitian yang digunakan yaitu metode deskriptif dengan pendekatan yang bersifat kualitatif. Terbentuknya komunitas tidak terlepas dari kebutuhan individu untuk berada dalam rasa aman dan memiliki mekanisme pertahanan ketika menghadapi situasi yang membahayakan. Komunitas mengembangkan suatu pengetahuan untuk memahami cara kerja alam, dan kemudian mengikutinya, serta berupaya menghindari apa yang dapat mengancam keselamatan. Kearifan lokal seharusnya dimaknai sebagai pengetahuan komunitas tentang keadaan setempat, atau kearifan setempat, yaitu pengetahuan yang menjawab situasi setempat, yang mana di tempat lain tidak ada. Suatu manajemen bencana alam perlu memperjelas kedudukan komunitas, serta memberi ruang gerak komunitas untuk menggunakan seluruh modal utama yang dimilikinya, yaitu diri (komunitas) dan kearifannya.
\end{abstract}

Kata kunci: komunitas, kearifan setempat, manajemen bencana alam

Abstract. This study aims to examine the local wisdom of the community as social capital in the management of natural disasters to obtain a full picture of the substantive meaning of the community, local wisdom and management of natural disasters. The research method used is descriptive method with a qualitative approach. The formation of a community is inseparable from the individual's need to be in a sense of security and to have a defense mechanism when facing a dangerous situation. The community develops a knowledge to understand how nature works, and then follows it, and seeks to avoid what can threaten safety. Local wisdom should be interpreted as community knowledge about local conditions, or local wisdom, namely knowledge that answers the local situation, which is not available elsewhere. A management of natural disasters needs to clarify the position of the community, and provide space for the community to use all the main capital they have, namely themselves (the community) and their wisdom.

Keywords: community, local wisdom, natural disaster management

\section{PENDAHULUAN}

Pada hari Sabtu Wage tanggal 27 Mei 2006 terjadi peristiwa gempa bumi berkekuatan 5,9 pada Skala Richter, sekitar pukul 05.53, berlangsung selama 57 detik. Peristiwa tersebut melanda wilayah Daerah Istimewa Yogyakarta dan Kabupaten Klaten di Jawa Tengah. Badan Meteorologi Klimatologi dan Geofisika menginformasikan bahwa pusat gempa berjarak 35 kilometer arah selatan kota Yogyakarta, pada kedalaman 33 kilometer. Kabupaten Bantul merupakan wilayah yang menerima dampak gempa bumi paling parah.

Dampak dari bencana alam gempa bumi sangat memilukan dan di luar jangkauan nalar warga yang menjadi korban. Korban manusia, baik yang meninggal maupun yang luka-luka jumlahnya sangat banyak. Kerusakan yang ditimbulkan teramat besar dan luas, mulai dari rumah-rumah penduduk, sarana dan prasarana kegiatan ekonomi masyara- kat, fasilitas umum dan sosial, serta infrastruktur lainnya. Data-data mengenai jumlah korban dan kerusakan rumah penduduk akibat gempa bumi 27 Mei 2006 di Kabupaten Bantul dapat dilihat pada Tabel 1 dan 2.

Kondisi yang sangat sulit muncul pada saat terjadi bencana dan sesaat setelah bencana. Ketidaksiapan harus berhadapan dengan banyaknya masalah yang datang dalam waktu yang bersamaan sehingga menimbulkan kepanikan di tengah-tengah masyarakat. Kepanikan dan kesedihan berdampak secara psikis sehingga menyebabkan korban bencana menjadi trauma. Masykur (2006) mengatakan bahwa duka cita yang mendalam dari para korban gempa mengakibatkan emosi semakin meningkat, mudah tersinggung, perubahan mood (suasana hati) yang cepat antara senang dan sedih, sangat cemas dan tegang (nervous), atau bahkan menjadi depresi. 
Tabel 1. Jumlah Korban Akibat Gempa Bumi 27 Mei 2006 (per 26 Juni 2006)

\begin{tabular}{|c|c|c|c|c|c|}
\hline Kecamatan & Meninggal & Luka-Luka & Kecamatan & Meninggal & Luka-Luka \\
\hline Bambanglipuro & 607 & 100 & Pajangan & 36 & 131 \\
\hline Banguntapan & 236 & 1.009 & Pandak & 112 & 933 \\
\hline Bantul & 247 & 239 & Piyungan & 243 & 705 \\
\hline Dlingo & 18 & 581 & Pleret & 519 & 4.855 \\
\hline Imogiri & 318 & 748 & Sanden & 2 & 32 \\
\hline Jetis & 830 & 223 & Sedayu & 3 & 49 \\
\hline Kasihan & 57 & 1.035 & Sewon & 462 & 350 \\
\hline Kretek & 26 & 230 & Srandakan & 5 & 48 \\
\hline Pundong & 422 & 758 & Jumlah & 4.143 & 12.026 \\
\hline
\end{tabular}

Sumber: Bappeda Bantul, 2006

Tabel 2. Kerusakan Rumah Penduduk

\begin{tabular}{lrrr}
\hline Kecamatan & \multicolumn{1}{l}{$\begin{array}{l}\text { Rusak } \\
\text { Total }\end{array}$} & $\begin{array}{c}\text { Rusak } \\
\text { Berat }\end{array}$ & \multicolumn{1}{c}{$\begin{array}{c}\text { Rusak } \\
\text { Ringan }\end{array}$} \\
\hline Babanglipuro & 6.587 & 2.732 & 816 \\
Banguntapan & 5,557 & 8.232 & 7.452 \\
Bantul & 4.708 & 7.338 & 3.301 \\
Dlingo & 1.377 & 3.380 & 4.720 \\
Imogiri & 5.664 & 5.354 & 11.781 \\
Jetis & 11.356 & 2.610 & 664 \\
Kasihan & 1.790 & 4.657 & 11.946 \\
Kretek & 1.121 & 4.665 & 2.486 \\
Pajangan & 1.228 & 2.216 & 2.610 \\
Pandak & 2.966 & 5.760 & 4.069 \\
Piyungan & 5.514 & 4.801 & 3.135 \\
Pleret & 8.139 & 2.322 & 1.438 \\
Sanden & 97 & 2.052 & 4.650 \\
Sedayu & 243 & 1.800 & 4.591 \\
Sewon & 8.281 & 8,496 & 6.004 \\
Srandakan & 342 & 3.054 & 3.506 \\
Pundong & 6.793 & 1.903 & 500 \\
\hline
\end{tabular}

Sumber: Bappeda Bantul, 2006

Aktivitas pemerintahan dapat dikatakan tidak berjalan secara optimal karena aparat birokrasinya, sebagaian besar, juga menjadi korban gempa bumi. Pemerintah tidak mungkin mengambil peran utama untuk mengatasi dampak bencana alam gempa bumi. Modal utama manajemen bencana alam ada pada komunitas. Semua upaya penanganan proses pemulihan paska gempa bumi (rehabilitasi, rekonstruksi dan rekonsiliasi) dilakukan dengan pendekatan khusus, yaitu perspektif korban atau komunitas dengan kearifannya agar dapat melakukan identifikasi semua masalah dan kebutuhan secara menyeluruh, termasuk harapan terhadap proses pemulihan kehidupannya.

Mungmachon (2012) menjelaskan pengertian komunitas dengan mengatakan:

"...The people in the community live together by giving and helping without expecting anything in return. They all consider themselves to be related to every other person in the community. They share what they have with neighbors thus ensuring the survival of the families and the community..." Komunitas merupakan kelompok sosial sebagai tempat hidup bersama dari orang-orang yang saling memberi dan membantu tanpa pamrih atau tanpa mengharapkan balasan apapun. Komunitas mempunyai budaya dan sistem pengetahuan sendiri, yang dijalankan oleh setiap anggotanya sebagai kearifan lokal komunitas. Menurut Yusutria, dkk., (2018) kearifan lokal merupakan de-ide lokal yang baik dan bijak, penuh kearifan, yang tertanam dan diikuti seluruh anggota komunitas. Kearifan lokal merupakan pengetahuan tradisional yang menjadi acuan dalam berperilaku dan telah dipraktekkan secara turun-temurun untuk memenuhi kebutuhan dan tantangan dalam kehidupan suatu masyarakat (Permana, dkk., 2011). Pengetahuan tersebut dapat memfasilitasi proses pencegahan, kesiapsiagaan, dan respons bencana dengan cara yang hemat biaya, partisipatif, dan berkelanjutan (Jha, et al, 2011). Pengetahuan tersebut telah diterapkan oleh masyarakat selama berabad-abad untuk mengatasi bencana alam (Ngwese, et al, 2018). Dengan demikian, kearifan lokal merupakan modal sosial bagi masyarakat untuk menjawab berbagai masalah kehidupannya, termasuk mengatasi dampak bencana alam.

Bencana merupakan kejadian luar biasa (hazard) yang menimpa komunitas yang rentan (vulnerable) sehingga masyarakat tidak mampu mengatasi dampak dari kejadian luar biasa tersebut. Berbagai bencana alam yang terjadi selama beberapa dekade pada gilirannya menimbulkan respons, pengalaman dan pengetahuan masyarakat (Alwi, et al, 2017). Habibullah (2013) mengatakan bahwa masyarakat lokal dengan ancaman bencana bukanlah pihak yang tidak berdaya, apabila agenda pengurangan risiko bencana bukan lahir dari kesadaran atas kapasitas komunitas lokal serta prioritas yang dimiliki oleh komunitas maka upaya tersebut tidak mungkin berkelanjutan. Basis kearifan lokal menjadi lokus dalam melakukan inovasi penaggulangan bencana berbasis komunitas (Zamroni, 2011). Berdasarkan latar 
belakang tersebut, penelitian ini dilakukan dengan tujuan untuk mengkaji kearifan lokal komunitas sebagai modal sosial dalam manajemen bencana alam sehingga memperoleh gambaran secara utuh tentang makna substantif dari komunitas, kearifan lokal dan manajemen bencana alam.

\section{METODE PENELITIAN}

Penelitian ini dilakukan di 13 kecamatan di wilayah Kabupaten Bantul. Dalam penelitian ini, peneliti sekaligus sebagai korban. Penelitian berlangsung selama dua tahun, yaitu tahun 2006-2008, dimulai saat fase tanggap darurat, rehabilitasi, rekonstruksi sampai dengan rekonsiliasi komunitas. Informan dalam penelitian ini sebanyak 33 orang. Pada saat itu penulis menjadi Staf Ahli Bupati Bantul sehingga keterlibatan dalam proses pemulihan paska bencana alam gempa bumi sangat intensif dan mendalam. Data lapangan yang diperoleh di-upgrade dan diolah selama dua bulan, yaitu bulan Maret-April 2019.

Penelitian ini bersifat kualitatif dengan menggunakan metode deskriptif analitis. Teknik pengumpulan data dilakukan melalui studi pustaka dan penelitian lapangan. Studi pustaka meliputi seluruh referensi yang relevan dengan penelitian, yaitu peraturan perundang-undangan, Surat Keputusan Bupati dan Gubernur, jurnal ilmiah, buku, media cetak, dan data-data dari website. Penelitian lapangan dilakukan dengan cara observasi, wawancara mendalam (indepth interview), penyebaran kuisener dan Focus Group Discussion (FGD).

\section{HASIL DAN PEMBAHASAN}

\section{Komunitas}

Adakah yang secara spontan bersedia menjadi korban dari suatu keadaan tertentu yang mengancam keselamatan seseorang atau sekelompok orang?

Konsepsi tentang korban menunjukkan bahwa tidak ada yang bersedia begitu saja mengalami kerugian, penderitaan atau kehilangan nyawa, kecuali untuk alasan-alasan yang dapat dibenarkan. Apakah ada suatu norma yang dapat membenarkan hilangnya keselamatan orang atau sekelompok orang? Suatu upaya mengatasi keadaan tertentu yang membahayakan untuk mendapatkan keselamatan dan keamanan, selalu akan muncul, bagaimana pun bentuknya, termasuk ketika menghadapi bencana alam, seperti gempa bumi.

Ketentuan tersebut sesungguhnya merupakan konstitusi kehidupan yang berlaku umum. Apa yang dapat dikatakan sebagai pembeda antara seseorang atau sekelompok orang dengan yang lain, dalam menghadapi situasi membahayakan, seperti bencana gempa bumi, adalah daya responsinya atau daya menyelamatkan diri. Daya tersebut datang dari dalam diri setiap orang, dan secara komunitas, menjadi suatu bentuk mekanisme pertahanan diri yang terbangun bersamaan terbentuknya suatu komunitas, dengan nilai-nilai atau nor- ma yang mengikat kehidupannya.

Keadaan mengancam atau keadaan bahaya dapat dibedakan dalam dua bentuk. Pertama, keadaan yang mengancam individu. Dan kedua, keadaan yang mengancam komunitas. Setiap individu memiliki naluri alamiah mempertahankan diri, baik secara internal dalam kedudukannya sebagai makhluk biologi, maupun secara sosial. Dalam konteks ini, relasi sosial dibangun atau terbangun sebagai bagian dari pertahanan diri, yaitu ketika suatu ancaman datang atau suatu musibah datang, maka diharapkan datang pertolongan dari sekeliling (komunitas). Srawung atau bergaul merupakan bagian dari mekanisme sosial yang menunjukkan bahwa seseorang tidak dapat menjadi dirinya sendiri, terpisah dari yang lain, sebaliknya dia harus bergabung atau bersosialisasi agar tidak mendapatkan sanksi sosial berupa pengucilan. Konsep srawung, dengan demikian, bukanlah ide tentang mencapai sesuatu, akan tetapi lebih condong kepada ide tentang "menghindar dari" (sanksi sosial).

Kedua, keadaan yang mengancam komunitas. Upaya individu untuk menjadi bagian dari yang lain, dengan tujuan membangun mekanisme pertahanan diri, jika suatu saat menghadapi ancaman, merupakan faktor utama pembentukan komunitas. Pembentukan komunitas tentu mengacu pada suatu wilayah geografis tertentu, sebagai tempat dimana komunitas tersebut menetap. Jika merunut proses terjadinya komunitas di wilayah tertentu, maka akan didapati kisah tentang saat awal dimana penghuni wilayah tersebut masih terbatas, dan sejalan dengan berjalannya waktu, bertambah secara alamiah, baik karena pertumbuhan dari dalam, maupun kehadiran dari luar yang dapat diterima oleh yang terdahulu. Dalam sebuah komunitas selalu ada cerita yang datang dan pergi. Demikian pula cerita tentang seseorang yang tidak dapat diterima, baik karena ketidakmampuan pribadi bergabung dalam komunitas, maupun karena dipandang membahayakan yang lain. Sejauh pribadi yang tidak bersosialisasi tidak mengancam yang lain, dan terutama tidak mengancam keseluruhan, maka kehadirannya masih dapat diterima, kendati diperlakukan secara khusus.

Dengan demikian, terbentuknya komunitas tidak lepas dari kebutuhan individu-individu untuk berada dalam rasa aman dan memiliki mekanisme pertahanan, ketika menghadapi situasi yang membahayakan. Hal inilah yang dapat menjelaskan tentang keberadaan berbagai tata cara sistem pertahanan di dalam komunitas, misalnya jaga air (di bidang pertanian, yaitu memastikan air mengalir ke sawahsawah mereka, dan tidak ada sabotase atau pencurian), atau ronda, yang kemudian diadopsi negara sebagai siskamling. Selain itu, komunitas di pedesaan juga mengenal upacara tolak bala, atau upacara sejenis, yang dapat dibaca sebagai mekanisme pertahanan melalui dimensi spiritual. Semuanya itu menjelaskan bahwa kebersamaan dalam formasi komunitas sebenarnya adalah ekspresi pertahanan. 


\section{Kearifan Setempat}

Bagaimana cara komunitas menghadapi suatu keadaan yang dipandang mengancam? Apakah komunitas mengembangkan suatu teknik tersendiri? Apakah mekanisme yang dikembangkan oleh komunitas dapat diterima sebagai suatu sistem pengetahuan, sebagaimana yang dikembangkan dunia ilmu? Hal yang nyata bahwa cara kerja komunitas tidak didasarkan pada prosedur ketat dan baku sebagaimana cara kerja dunia ilmu. Pertanyaan bagi dunia ilmu adalah apakah nalar tersebut akan dapat diterima sebagai sistem pengetahuan, setidak-tidaknya sistem pengetahuan yang berbeda dengan yang dikembangkan oleh dunia ilmu, ataukah tidak? Penyebutan kearifan lokal dapat dikatakan sebagai suatu ekspresi yang menempatkan sistem pengetahuan yang dikembangkan komunitas tidak disebut sebagai suatu sistem pengetahuan, melainkan sebagai suatu bentuk kearifan.

Fakta menunjukkan bahwa komunitas mengembangkan suatu pengetahuan untuk mengerti cara kerja alam, dan kemudian mengikutinya, serta berupaya menghindari apa yang dapat mengancam keselamatan. Pengetahuan tentang bagaimana membangun rumah dan rumah tangga; pengetahuan tentang bercocok tanam, atau tradisi perladangan dengan aturan pemilihan lokasi ladang (huma), waktu berladang, tata cara membuka dan membakar lahan, serta menghindarkan dari bahaya longsor, dan kebakaran (Suparmini, dkk., 2014), merupakan contohcontoh tentang bagaimana komunitas mengembangkan ilmu untuk bertahan dan mengembangkan kehidupan.

Pengetahuan masyarakat lokal mengenai perilaku alam, hewan dan pergerakan konstruksi alam tertentu dipahami sebagai bentuk-bentuk perilaku alam yang memberikan sinyal bagi masyarakat lokal bahwa akan terjadinya bencana dan hal-hal tersebut lebih dipercaya dan diyakini kebenarannya oleh masyarakat setempat bila dibandingkan dengan menggunakan peralatan canggih sebagai alat peringatan bencana (Santoso, dkk., 2018).

Gambaran tersebut menjelaskan bahwa apa yang disebut sebagai kearifan setempat merupakan sistem pengetahuan setempat yang tersimpan dalam ingatan komunitas dan akan langsung bekerja ketika keadaan yang mensyaratkannya untuk bekerja telah datang. Peristiwa gempa bumi 27 Mei 2006, yang meluluhlantakkan bangunan dan berbagai prosedur formal, menjadi saksi nyata dari kehadiran kearifan setempat yang secara otomatis hadir dan bekerja. Tentu pribadipribadi yang selamat, mengalami goncangan beberapa saat, tetapi setelah itu, bekerja suatu mekanisme yang dapat dikatakan sebagai kearifan setempat. Mengapa dikatakan demikian? Karena secara kongkrit seluruh mekanisme formal pemerintahan tidak dapat bekerja, bahkan pun prosedur formal di rumah sakit, karena korban datang dalam jumlah besar dan pada waktu yang bersamaan.

\section{Manajemen Bencana Alam}

Mungkinkah suatu usaha yang bersifat menyeluruh, yaitu sejak sebelum kejadian sampai setelah kejadian? Bagi suatu studi untuk keperluan ilmu pengetahuan atau keperluan perencanaan pembangunan, tentu pertanyaan tersebut merupakan hal yang wajar, bahkan sudah seharusnya demikian. Tetapi, apakah layak pertanyaan tersebut diajukan kepada komunitas? Jika layak mengapa, dan jika tidak bagaimana menjelaskannya?

Sebagaimana telah diketahui bahwa peristiwa gempa bumi 27 Mei 2006 di Kabupaten Bantul dan sekitarnya, serta bencana tsunami di Aceh, telah menyadarkan banyak pihak, terutama para pemegang otoritas negara, bahwa kesiapan menghadapi bencana sangat dibutuhkan. Kesadaran tersebut tidak saja memunculkan banyak insiatif, tetapi juga mendorong munculnya Undang-Undang No.24 tahun 2007 tentang Penanggulangan Bencana.

Dalam undang-undang tersebut dinyatakan secara legal bahwa yang disebut dengan bencana adalah peristiwa atau rangkaian peristiwa yang mengancam dan mengganggu kehidupan dan penghidupan masyarakat yang disebabkan, baik oleh faktor alam dan/atau faktor non alam maupun faktor manusia sehingga mengakibatkan timbulnya korban jiwa manusia, kerusakan lingkungan, kerugian harta benda, dan dampak psikologis. Selanjutnya penyelenggaraan penanggulangan bencana adalah serangkaian upaya yang meliputi penetapan kebijakan pembangunan yang berisiko timbulnya bencana, kegiatan pencegahan bencana, tanggap darurat, dan rehabilitasi.

Dari pengertian tersebut dapat dikatakan bahwa upaya penanggulangan bencana bukanlah wilayah bebas, dimana setiap orang atau kelompok orang (komunitas) dapat dengan begitu saja mempersiapkan langkah-langkah tertentu. Pemerintah dan Pemerintah Daerah adalah pihak yang menjadi penanggung jawab dalam penyelenggaraan penanggulangan bencana.

Penanggulangan bencana merupakan bagian dari pembangunan nasional, yaitu serangkaian kegiatan penanggulangan bencana sebelum, pada saat maupun sesudah terjadinya bencana. Ketentuan tersebut memperlihatkan dengan jelas bahwa manajemen bencana merupakan upaya yang bersifat formal, mengikuti ketentuan yang berlaku, artinya rangkaian kegiatan tersebut merupakan bagian dari kebijakan pembangunan, sedemikian rupa sehingga harus mengikuti kaidah -kaidah formal yang telah ditetapkan.

Dalam rumusan tersebut, dimanakah tempat dari komunitas? Pertanyaan ini penting dimajukan, bukan untuk membuat masalah menjadi semakin rumit, melainkan agar duduk persoalan menjadi lebih jelas, dan dengan itu dapat diperoleh pelajaran dan makna yang lebih dalam.

Kalau saat ini diajukan pertanyaan di atas kepada komunitas yang menjadi korban bencana gempa bumi 27 Mei 2006 yang lalu, apakah mereka telah mempersiapkan 
diri? Tentu pertanyaan ini akan terasa aneh, bahkan mungkin mengusik ketenangan rasa batin mereka. Pertanyaan tersebut seakan-akan mengajak mereka mengenang kembali subuh kelabu di hari Sabtu tersebut. Kalau pun pertanyaan tersebut tetap diajukan, apakah ada jawaban lain selain mengatakan siap? Apakah ada ruang bagi perkataan tidak siap? Tentu tidak ada. Jika pertanyaan tersebut dihadapkan dengan realitas keseharian mereka, maka mungkin tidak ditemukan tanda-tanda kesiapan tersebut. Mengapa? Pertanyaan ini dapat dijawab dengan datang kepada peristiwa dinamis yang berlangsung paska bencana gempa, baik masa tanggap darurat maupun masa rehabilitasi dan rekonstruksi. Pertama, kejadian yang dapat disebut sebagai kesenjangan antara kebutuhan dan jumlah bantuan. Pada hari pertama dan kedua, suatu keadaan "ketegangan" kecil telah terjadi, yaitu antara korban dengan pengelolaan bantuan, dan dengan para penghimpun bantuan. Berita tentang bantuan yang belum sampai, bantuan yang tidak merata, dan atau penyaluran bantuan yang kacau menjadi bagian dari dinamika tanggap darurat.

Kedua, kejadian yang dapat disebut sebagai kesenjangan antara kenyataan (kerusakan) dan kemampuan (membantu). Situasi ini muncul secara vulgar, dalam bentuk aksi warga yang mengecam pemerintah, karena dianggap ingkar janji. Kejadian dipicu oleh pernyataan Wakil Presiden yang mengatakan bahwa pemerintah akan membantu setiap rumah yang rusak (dengan kategori tertentu) sebesar Rp. 30.000.000,00. Masalah muncul, karena setelah dihitung ternyata rumah rusak jauh dari apa yang diduga. Rumah rusak di Kabupaten Bantul akibat gempa bumi, mencapai lebih dari 200 ribu rumah.

Ketiga, kejadian yang dapat disebut sebagai kesenjangan antara kompleksitas masalah dengan instrumen yang tersedia. Situasi ini berlangsung dalam masa rekonstruksi. Muncul polemik apakah bantuan rekonstruksi rumah rusak akan diurus langsung oleh pemerintah melalui kontraktor, ataukah ada cara lain? Juga polemik tentang apakah bantuan yang ada dibagi rata (jumlah bantuan dibagi dengan jumlah korban), ataukah dibagi secara adil (jumlah bantuan disesuaikan dengan kebutuhan korban, yang mengikuti tingkat kerusakan rumah korban).

Penelitian ini menilai bahwa ketiga soal tersebut sesungguhnya mencerminkan adanya dialog antara "pengetahuan keadaan nyata" (yang dalam hal ini hanya dimiliki korban) dan ketidaktahuan atau "pengetahuan yang kurang lengkap"; antara yang formal dan yang informal; antara sentralisasi dan desentralisasi. Intinya adalah dialog substansial antar korban dan para pihak yang ingin, maupun pihak yang berkewajiban membantu. Soalnya adalah apakah skema bantuan mengikuti nalar korban ataukah mengikuti nalar pihak lain? Pengalaman mengatasi bencana gempa bumi 27 Mei 2006 di Kabupaten Bantul, memberikan pelajaran penting tentang bagaimana dialog tersebut berlangsung, dan pada akhirnya ditemukan jalan tepat, sehingga proses rehabilitasi dan rekonstruksi, dapat berlangsung secara cepat dan baik, tentu dengan tidak mengabaikan berbagai masalah yang muncul.

Hasil dialog yang dimaksud adalah pertama, korban merupakan pihak yang paling berkepentingan dengan pemulihan keadaan, sejak masa tanggap darurat sampai pada masa rekonstruksi, baik fisik maupun sosial. Hal pertama yang dapat ditunjuk sebagai bukti mulai bekerja kearifan setempat adalah gerak cepat komunitas sesaat setelah terjadi bencana gempa bumi, yaitu menyelamatkan keluarga dan sanak saudara yang masih dapat diselamatkan (Gambar 1).

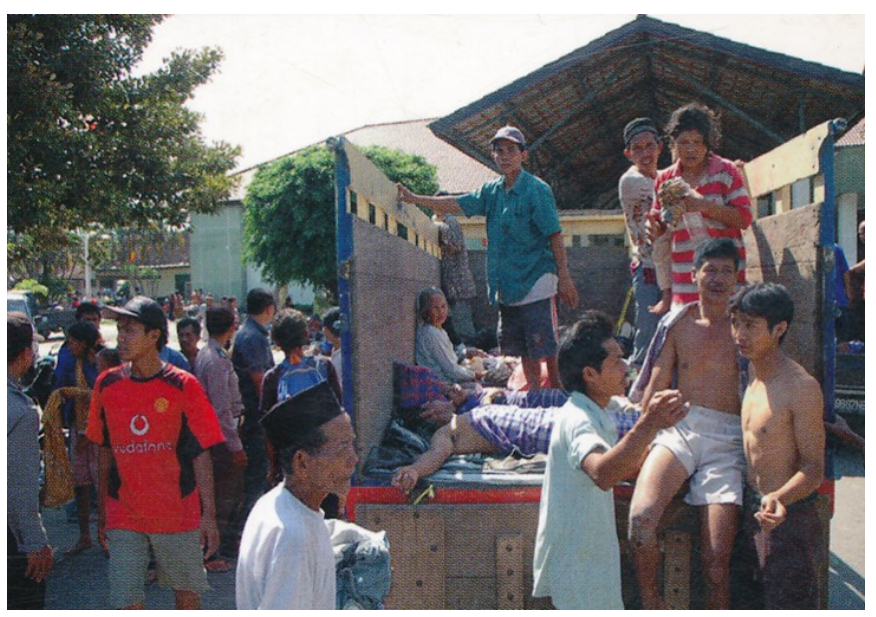

Gambar 1. Warga saling menolong korban gempa bumi (Sairin, dkk., 2008)

Tahap ini merupakan tahap yang paling menentukan, yaitu suatu upaya untuk keluar dari kesediaan dan ketidakpastian menuju kehidupan baru yang memang belum jelas ujungnya. Kemampuan untuk keluar dari situasi tersebut, harus dibaca sebagai proses integrasi komunitas, yaitu ketika antar individu mulai menyadari bahwa masalah yang datang bukan hanya dialami oleh diri sendiri, melainkan juga dialami yang lain, seluruh warga.

Kedua, dari para pihak yang membantu korban, baik Pemerintah maupun berbagai kelompok sosial (baik dalam maupun luar negeri), mengambil posisi sebagai pihak yang bertugas untuk meningkatkan kuantitas dan kualitas bantuan, serta memberikan ruang gerak bagi korban untuk memulihkan keadaan. Salah satu contoh yang bisa ditunjukkan yaitu Pemerintah memutuskan tidak menggunakan kontraktor untuk membangun kembali rumah-rumah warga, tetapi memberikan kepercayaan sepenuhnya kepada warga untuk membangun kembali rumahnya secara bergotongroyong (Gambar 2). Inilah titik pijak pertama dan utama, yang membuka energi sosial dan menggerakkan langkah warga secara bersama-sama. Tentu proses ini tidak berjalan mulus, selalu ada dinamika, akan tetapi dinamika tersebut lebih mencerminkan suatu dialog antara korban dan pihak luar, antara nalar komunitas (korban) dan tata kelola yang didasarkan pada nalar normal (kendati dikatakan sebagai prosedur tanggap darurat). 


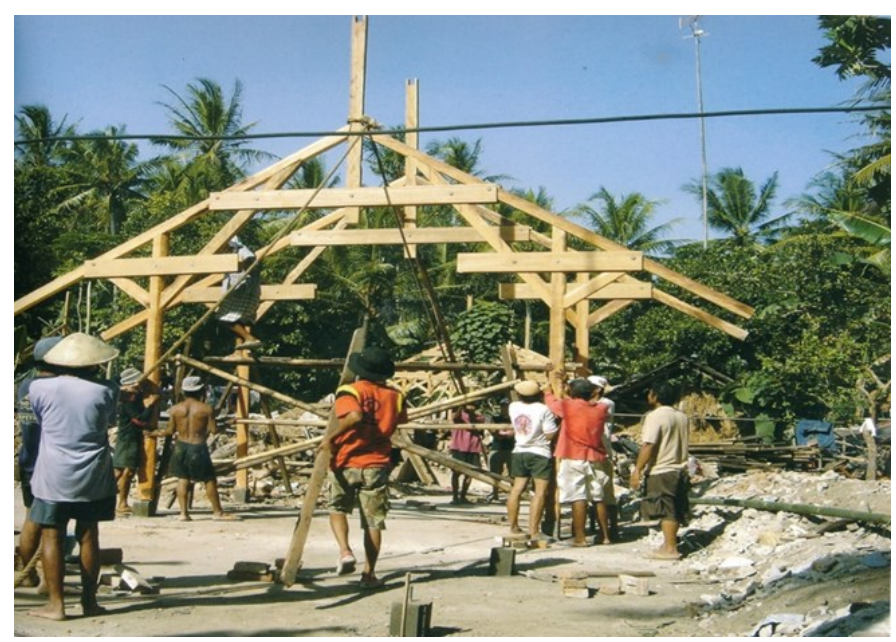

Gambar 2. Warga gotong royong membangun kembali rumahnya (Sairin, dkk., 2008)

Kemampuan komunitas tersebut kalau dilihat dari sudut sebelum peristiwa bencana gempa bumi terjadi, dalam perspektif manajemen bencana dapat dikatakan sebagai keadaan tanpa kesiapan. Tidak ada persiapan, karena tidak ada satupun yang menginginkan datangnya bencana. Pertanyaannya, mengapa paska kejadian, dapat segera terbangun suatu formasi unik penanggulangan, dan kelak menjadi faktor yang menentukan jalannya proses pemulihan? Jawabannya terletak pada kenyataan bahwa kearifan setempat merupakan modal yang ada di dalam diri komunitas. Modal tersebut tidak tersimpan di tempat terbuka, dalam bentuk prosedur formal, panduan atau berbagai penanda lain. Modal tersebut tersimpan rapi di dalam memori komunitas.

Oleh karena itu, kepada komunitas sebenarnya tidak perlu ditanyakan tentang kesiap-siagaan, karena dengan sendirinya hal tersebut dipersiapkan. Hal yang mungkin menjadi soal adalah ketika ada kebutuhan untuk menyeragamkan atau memformalkan persiapan atau kesiapsiagaan tersebut, seperti pembentukan unitunit kerja atau sekedar memasang plang atau baliho, yang menyebut komunitas sadar bencana. Bagi komunitas semua upaya tersebut diterima dan diikuti begitu saja, sepanjang waktu memungkinkan. Perhatian komunitas dan anggota komunitas (warga, orang per orang), lebih kepada upaya menghadapi apa yang ada di depan mata, yaitu melanjutkan kehidupan, dimana mereka harus menyambung hidup dan kehidupan. Jika mereka sibuk mempersiapkan diri sebagaimana maksud dari program-program pemberdayaan di bawah predikat sadar bencana, tentu kesulitan baru akan datang.

Untuk itu, suatu manajemen bencana amat perlu mempertimbangkan susunannya, dengan pertama-tama memperjelas kedudukan komunitas, dan sekaligus menegaskan sudut pandang mana yang akan menjadi sudut pandang utama. Kalau dituntut digunakan sudut pandang komunitas, tentu akan menimbulkan persoalan tersendiri, karena seluruh sistem yang ada bekerja dengan nalar formal, sementara komunitas bekerja dalam nalar informal. Sebaliknya, jika digunakan sepenuhnya nalar formal birokrasi, tentu akan menimbulkan soal tersendiri bagi komunitas. Jalan paling mungkin adalah suatu formasi manajemen bencana yang mengkombinasikan kedua nalar tersebut. Formasi yang dimaksud yaitu suatu tata kerja yang memberi ruang gerak bagi komunitas untuk menggunakan seluruh modal utama yang dimilikinya, yaitu diri (komunitas) dan kearifannya.

\section{KESIMPULAN}

Upaya individu untuk menjadi bagian dari yang lain, dengan tujuan membangun mekanisme pertahanan diri, jika suatu saat menghadapi ancaman, merupakan faktor utama pembentukan komunitas. Pembentukan komunitas tentu saja mengacu pada suatu wilayah geografis tertentu, sebagai tempat dimana komunitas tersebut menetap. Kebersamaan dalam formasi komunitas sebenarnya merupakan ekspresi pertahanan.

Komunitas mengembangkan suatu pengetahuan untuk memahami cara kerja alam, dan kemudian mengikutinya, serta berupaya menghindari apa yang dapat mengancam keselamatan. Kearifan lokal seharusnya dimaknai sebagai pengetahuan komunitas tentang keadaan setempat, atau kearifan setempat, yaitu pengetahuan yang menjawab situasi setempat, yang mana di tempat lain tidak ada.

Suatu manajemen bencana alam perlu memperjelas kedudukan komunitas dan sudut pandang utama yang hendak digunakan, serta memberi ruang gerak komunitas untuk menggunakan seluruh modal utama yang dimilikinya, yaitu diri (komunitas) dan kearifannya.

\section{DAFTAR PUSTAKA}

Alwi, Idaman, et al, (2017). Natural Disaster Managements In Indonesia: Perspective of Local Wisdom and Heidegger Hermeneutics, AL ALBAB Volume 6 Number 1 June 2017.

Habibullah, (2013), Kebijakan Penanggulangan Bencana Berbasis Komunitas: Kampung Siaga Bencana Dan Desa/Kelurahan Tangguh Bencana, Majalah

Informasi, Vol. 18, No. 02, Tahun 2013, hal. 133 - 149.

Jha, Vanya, et al, (2011), Traditional Knowledge on Disaster Management: A preliminary study of the Lepcha Community of Sikkim, India, Indian Journal of Traditional Knowledge Vol.10 (1), January 2011, pp 173-182.

Masykur, Achmad M., (2006), Potret Psikososial Korban Gempa 27 Mei 2006 (Sebuah Studi Kualitatif di Kecamatan Wedi dan Gantiwarno, Klaten), Jurnal Psikologi Universitas Diponegoro Vol.3 No. 1, Juni 2006.

Mungmachon, Miss Roikhwanphut, (2012), Knowledge and Local Wisdom: Community Treasure, International Journal of Humanities and Social Science Vol. 2 No. 13; July 2012.

Ngwese, Nsioh Macnight, et al, (2018), Traditional and Local Knowledge Practices for Disaster Risk Reduction in Northern Ghana, Sustainability 2018, 10, 825; doi:10.3390/ su10030825.

Permana, Raden Cecep Eka, dkk., (2011), Kearifan Lokal Tentang Mitigasi Bencana Pada Masyarakat Baduy, Jurnal Makara, Sosial Humaniora, Vol. 15, No. 1, Juli 2011: 67-76.

Sairin, Sjafri, dkk., (2008), Bantul Bangkit Songsong Peradaban Baru, Yogyakarta: Pemerintah Daerah Bantul.

Santoso, Meilanny Budiarti, dkk., (2018), Mekanisme Masyarakat 
Lokal Dalam Mengenali Bencana Di Kabupaten Garut, Share Social Work Jurnal Volume 8 Nomor 2, Halaman: 142149, ISSN: 2339-0042 (p) ISSN: 2528-1577 (e).

Suparmini, dkk., (2014), Mitigasi Bencana Berbasis Kearifan Lokal Masyarakat Baduy, Jurnal Penelitian Humaniora, Vol. 19, No.1, April 2014: 47-64.

Zamroni, M. Imam, (2011), Islam Dan Kearifan Lokal Dalam Penanggulangan Bencana Di Jawa, Jurnal Dialog Penanggulangan Bencana Volume 2 Nomor 1, Tahun 2011.

Yusutria, dkk., (2018), Local Wisdom Values in Faceng Natural Disasters On Module of Geographic Planning Subject Based on Faith, International Journal of Progressive Sciences and Technologies (IJPSAT) ISSN: 2509-0119. 